\title{
Quality and Applicability: Two Necessary Requirements in Instruments That Measure Creative Potential, for Use in the Classroom
}

\author{
Nazira Píriz Giménez ${ }^{1}$, Joselín Cantero², Virginia Mallarini², \\ Jerónimo Tucci $^{3}$, Diana Shablico ${ }^{1,2}$, María Noel López Larrama ${ }^{1,2}$ \\ ${ }^{1}$ Profesorado Semipresencial, Consejo de Formación en Educación, Montevideo, Uruguay \\ ${ }^{2}$ Instituto de Profesores “Artigas”, Consejo de Formación en Educación, Montevideo, Uruguay \\ ${ }^{3}$ Instituto de Formación Docente de la Costa, Consejo de Formación en Educación, Montevideo, Uruguay \\ Email:nazirapiriz@gmail.com
}

How to cite this paper: Giménez, N. P., Cantero, J., Mallarini, V., Tucci, J., Shablico, D., \& Larrama, M. N. L. (2019). Quality and Applicability: Two Necessary Requirements in Instruments That Measure Creative Potential, for Use in the Classroom. Creative Education, 10, 3316-3328. https://doi.org/10.4236/ce.2019.1013255

Received: November 5, 2019

Accepted: December 8, 2019

Published: December 11, 2019

Copyright $\odot 2019$ by author(s) and Scientific Research Publishing Inc. This work is licensed under the Creative Commons Attribution International License (CC BY 4.0).

http://creativecommons.org/licenses/by/4.0/

(c) (i) Open Access

\begin{abstract}
Creativity is a growing demand in today's world. Education for creativity takes hierarchy, as well as the search for ways to evaluate its promotion. This paper presents partial results of a research project aimed at the study of the promotion of creative qualities in science education. The CREA test was used as an instrument to evaluate the creativity of students. The results allow us to propose limitations of this test as a tool for a global measure of creativity. The conventional analysis could measure one of the creative qualities: fluidity. The assessment of other creative qualities could benefit from a modified analysis. Some modifications like test time, could improve the measure of flexibility and elaboration. The applicability of the CREA test may not be accompanied by quality to the extent of creative potential.
\end{abstract}

\section{Keywords}

Promotion of Creativity in the Classroom, Creative Classrooms, Measure of Creativity, CREA Test, Creative Qualities

\section{Introduction}

At the moment the training of creative people is considered an urgent need, taking hierarchy its implementation in Education in general and in particular in the Teaching of Science (Píriz Giménez et al., 2018; Píriz Giménez, 2017a; Píriz Giménez et al., 2017; Píriz Giménez, 2017b; Píriz Giménez, 2016; Tan, 2014; Trnova \& Trna, 2014; Daud et al., 2012; Hadzigeorgiou et al., 2012; Rebollo \& Soubirón, 2014; Cachia et al., 2010; Soriano de Alencar, 2007; Kind \& Kind, 
2007).

The implementation of measures for its promotion requires the production of knowledge that allows the identification of favorable strategies in this regard. The valuation of creativity becomes essential, as well as the search and validation of tools that allow its measurement, whose application would be viable in the classroom. A reliable and practical tool is necessary for use in class. The review of instruments developed for these purposes constitutes an area of educational interest. This work aims to make contributions in this regard.

AN INELUDIBLE THEORETICAL FRAMEWORK: THE PSYCHOLOGY OF CREATIVITY

From the vast scientific bibliography that refers to the study of creativity, and in view of an analysis of the quality of instruments for its measurement, it is considered pertinent to rank and present the components indicated by MacKinnon. They are: - the creative person; - the creative process; - the creative product; and - the creative situation or context (MacKinnon, 1975).

Creative people

One of the most significant authors in the Psychology of Creativity has been Joy Guilford. According to Guilford (1975) "creative individuals are characterized by a combination of personality traits such as: sensitivity to problems, ideational fluidity, flexibility for adaptation, originality, synthesis capacity, analysis capacity, capacity for redefinition or reorganization, assimilation of complex data, ability to evaluate ideas".

Problematization and questioning are creative activities. This idea supports the CREA test by Corbalán and collaborators, who propose: "Generate multiple solutions to a problem... generate multiple problems to a solution. First is second... The first step in creativity consists of elaborating questions" (Corbalán Berná et al., 2003).

\section{The creative process}

In the creative process, Abraham Maslow distinguishes two phases: "primary creativity or inspiration phase, and secondary creativity referred to the process of elaboration and development of inspiration. It states that this second stage requires work, discipline, preparation, practices and essays, so it requires other qualities such as obstinacy, patience, industriousness, etc., in addition to the purely creative" (Huidobro Salas, 2004).

\section{The creative product}

Teresa Huidobro Salas (2004) states that: “The production of something new and adequate, that solves a problem that was vague or was poorly defined, supposes statistical rarity and a radical transformation of a previous state. In addition, said product must be transcendent and produce an impact."

\section{The creative situation or context}

In relation to creative contexts, Huidobro Salas (2004), in his study of 24 authors identifies 6 qualities in which at least $25 \%$ of the authors share as characteristic of creative contexts. They are: 
1) Access to training in the field of activity: contents and precedents

2) Availability of resources (economic and cultural)

3) Exposure to a variety of models and paragon in childhood

4) Recognition of creative behaviors during development

5) Family/social environment that promotes individualism

6) Absence of extrinsic obstacles and social pressure

Operational Definitions of Creativity

Creativity is currently considered to be a multidimensional construct, located on the border between cognition and personality (Wu et al., 2014), with researchers agreeing that it cannot be defined conceptually but operationally. Sternberg and Lubart (1992) consider that "to be creative, you need to generate ideas that are relatively new, appropriate and of high quality".

Qualities that aim to measure the creativity tests

Despite the impossibility of a conceptual definition of creativity, agreements have been reached in its characterization. Currently, the fundamental qualities of creativity are considered to be: originality, fluidity, flexibility and elaboration (Manriquez et al., 2005; Marín, 1980).

Fluidity, according to Marín: "It is the abundance of accomplishments that reveals the creative fluidity... While it is necessary to clarify this criterion with a qualitative selection of what is really worth it". According to Rael Fuster (2009), "Creative people give more answers to a question; they elaborate more solutions; they think more alternatives."

Originality is understood as what "appears in a small proportion in a given population" (Marín, 1980). The original is novel, unlikely, so the criteria for qualification is statistical.

Flexibility is related to divergence. According to Marín (1980) "the truly creative not only offer multiple and unusual answers but also correspond to different categories: the creative mind is placed in disparate points of view, sees innumerable possibilities and is able to select, among many divergent paths, the most valuable". Flexibility is the possibility of changing, transforming or renewing (Gala \& Dolores, 2007).

In relation to the elaboration, it is linked to the "inner discipline" necessary to complete the creative work. "The elaboration implies the requirement to complete the impulse until its completion" (Marín, 1980). According to Rael Fuster (2009), "the elaboration is based on analysis and synthesis. The analysis is about the ability to divide a reality into parts... synthesis is the ability to combine separate elements forming a whole, thus opposed to analysis." Both qualities have been considered essential by Guilford, in the creative person. According to Elisa Alvarez (2010), elaboration is the ability to decorate, to include details.

\section{Measure of creativity. CREA test}

The design of tools for the valuation of creativity has a long history in educational and psychological research. The complexity and difficulty in its assessment is recognized by researchers in this area of knowledge (Csikszentmihalyi, 
2006; Corbalán, 2008). Authors of various tests recognize that creativity is more complex than what they measure. "The study of the creative individual involves the study of his mind and his personality, the cognitive processes that are carried out in him, his emotional and motivational world" (Corbalán Berná et al., 2003).

The CREA test consists of images that are presented to people to be tested, requesting the formulation of as many questions as possible in relation to the figures. The test proposes 3 types of laminas (A, B and C) that are applied according to the age of the people, including children, adolescents and adults. The time spent asking questions is 4 minutes for each lamina, which facilitates its application in the classroom. The analysis of the test allows to obtain a score for each applied lamina that results from attributing a point to each question correctly formulated (and not repeated), and adding up all the points. This Figure 1 is searched in the corresponding scale, which establishes a certain percentile value for each score. The CREA allows to obtain then a score and a percentile for each applied lamina, as a global assessment of the creative potential, not discriminating each of its components (originality, fluidity, flexibility and elaboration). The CREA test presents scales for Argentina and Spain.

According to its authors, the CREA test “... is based on a theoretical model that directs its gaze to cognitive operations not identifiable with creative production, but of a necessary nature for the exercise of it. An indirect measurement of creativity is used; this is achieved by measuring a variable that, not being strictly productive, forces the cognitive system to activate the mechanisms involved in a creative activity. In short, the creative psychological style, as CREA examines it, will include a general disposition of the subject for the opening and versatility of his cognitive schemes" (Corbalán Berná et al., 2003).

\section{Methodological Design}

This work aims to contribute to the review of instruments developed for the measurement of creative potential, applicable in educational fields. Results of the

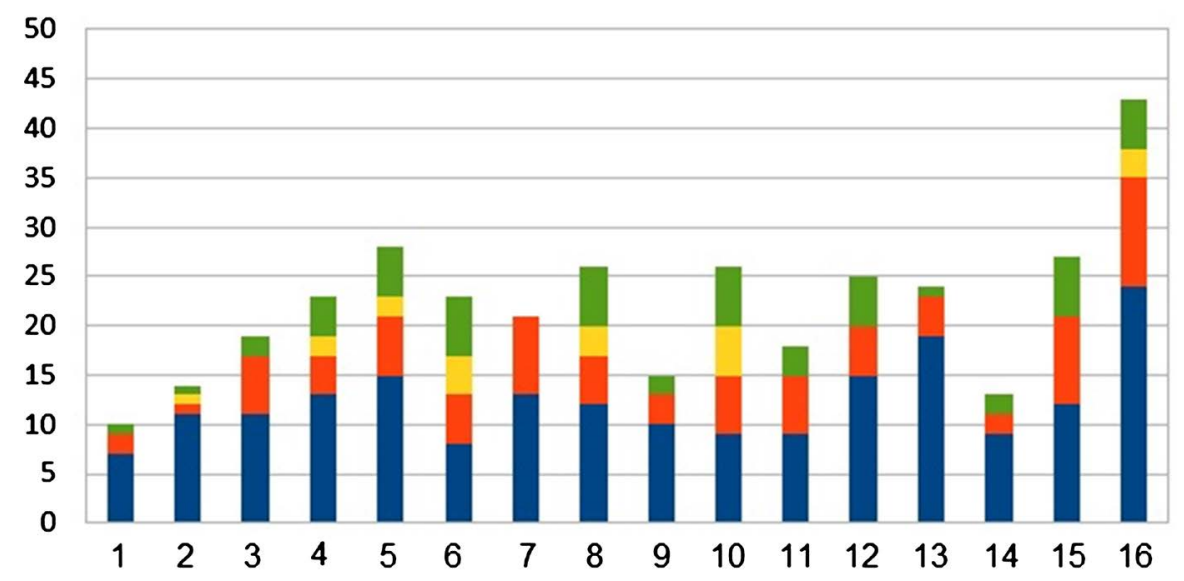

Figure 1. Global results and discriminated by quality (from bottom to top: fluidity, originality, flexibility and elaboration, for each student, with modified analysis of the CREA test. (In ordinates: score obtained, and in abscissa: student number). 
application of the CREA test are presented to a group of students of Biological Sciences Teachers of institutions dependent on the Education Training Council. It was framed in a broader project aimed at assessing the promotion of creative qualities through the design of activities promoting critical and divergent thinking, in various courses and levels. The results presented here correspond to adult students who voluntarily agreed to take the CREA test, always respecting their anonymity. The investigation was carried out with the authorization of the authorities of the Education Training Council (CFE).

The choice of the CREA test as a measure of creative potential was based on presenting said test scales for Argentina, a country with which Uruguay has an important cultural closeness, and makes it comparable. Additionally, it has the advantage of being able to apply simultaneously to dozens of students, and in a short time, which makes its use viable in Teaching fields. The CREA test was applied at the beginning of the school year to 100 students of the Faculty of Biological Sciences career, from various institutions dependent on the CFE. The test was applied individually and in person, and the analysis of the results was carried out following the guidelines of its authors (Corbalán Berná et al., 2003). We are particularly interested in discussing some difficulties that we verify during the analysis of the results, which we develop below.

\section{Results and Discussion}

During the analysis of the tests, elements were found that allow questioning its reliability as a global measure of creativity and which are developed below.

The CREA test proposes that the person who carries it out should elaborate as many questions as possible in relation to each proposed image (for adults: laminas $\mathrm{A}$ and $\mathrm{B}$ ). The manual for the application and analysis of the CREA test stipulates that the number of questions asked must be counted, assigning a point to each question and adding the total. That total number is searched in the manual scales, from which a percentile value is assigned.

The application and reflexive analysis of the test by the research team, allowed us to make some observable observations in view of the reliability of the measure of creative potential. Below are findings that merit your attention:

1) In tests with a high number of questions and therefore a high score, the questions elaborated were valued by the research team, as little original and/or little elaborated. As an example, questions referring to a certain object in the image were assessed in this way, such as: what is it, how does it work, what size is it, what material is it?

2) Tests were verified with a smaller number of questions and therefore a score and percentile also lower, with more elaborate, complex and original questions, which the research team understood should not be punctuated in the same way. As an example, questions such as: Why are we still held incommunicado? How are sounds transmitted through the wires? Were the wires supplanted by satellites? 
3) Repeated questions and other clearly original ones were corroborated. The most repeated questions were the simplest, while the most complex were original.

4) Groups of questions were found (in the same student) that implied positioning from the same perspective, while in other tests a greater diversity of perspectives was found. As an example, a student could ask questions only referring to the object that appeared on lamina $\mathrm{A}$, while others raised questions referring to who built the object, to the time it was built, to the way of life in other times, to general human issues divergent to the purpose of the picture.

The results of the application of plates A and B of the CREA test to two students in comparative form are attached in annex. In this way it is hoped to illustrate more clearly the difficulties described.

The data allow us to corroborate that a high score and percentile does not necessarily imply originality and elaboration in the questions asked. Concomitantly, lower scores and percentiles do not rule out originality, elaboration and divergence.

Taking into account the theoretical framework of Psychology of Creativity, and considering that there is agreement in the scientific field to characterize it by 4 qualities (originality, fluidity, flexibility and elaboration), we consider in view of the results, that of assigning the same score For all questions, a qualitative assessment of each question (in this case, "product") necessary to assess its quality from the point of view of creativity is not being made. That is, simple questions that are repeated in different people should be less valued than complex, original and raised questions from different positions.

It was considered that assigning the same score to all questions and therefore assessing the number but not its quality, allows only to assess the fluidity, but not other qualities of creativity. For this reason, we propose a modified analysis in order to contemplate "what is really worth it" (according to Marín). That is to say, the CREA test could eventually contemplate what according to Abraham Maslow corresponds to the primary phase of creativity or inspiration phase (fluid production) but not the second phase (secondary creativity), a stage that refers to the selection of the valuable, to the process of elaboration and development of inspiration.

Although this work was not proposed to validate a new analysis of the CREA test, modifications based on the theory of the Psychology of Creativity are proposed, in order to show possible notable changes in the results of the analysis and therefore in the assessment global creativity.

\section{Modified analysis of the CREA test}

Based on the foregoing, the research team considered that the score assigned to the CREA test corresponds to fluidity, requiring a modified analysis to obtain a broader assessment of Creativity. In order to analyze the benefits of a modified analysis, the team decided to work with a small number of students. A group of 16 students were chosen that showed all the observations described. The modified test analysis is intended to be a qualitative contribution to the discussion 
about its validity. For this reason it was decided that sampling would end once the defined categories began to saturate. This occurred when the number 16 of tests analyzed was reached. The score obtained from the analysis stipulated by Corbalán and co-authors was assigned the quality "fluidity", and to this value was added a new score for each of the remaining qualities of creativity: originality, flexibility and elaboration.

The criteria defined to assign a new score to these other 3 qualities are listed below. Each generated a new score that added to the original, now corresponding to the "fluidity".

\section{Criteria defined for assigning Originality scores}

In order to evaluate it, each question of the test was compared, each question asked with all the others (those asked by all students for that same lamina), and it was defined if it was an original or repeated question. Each of the original questions was assigned a new point. The quality "Originality" was assigned a score equal to the sum of points added by these questions. Repeated questions were assigned the value " 0 ".

On this occasion he was not discriminated against by the number of times a question was repeated. The original questions are therefore the only ones, which are not repeated in any case. No repeated questions were penalized by subtraction or reduction of the score.

\section{Defined criteria for assigning Flexibility scores}

To evaluate it, it was considered necessary to identify "points of view" or "perspectives" that went on to define categories. From the questions elaborated by each person, categories were defined according to perspectives in which it was positioned.

As an example, in the A test the image corresponded to an object. The categories considered to classify the questions were the following:

- They refer to the object of the image;

- They refer to the person who manufactured/created the object of the image;

- They refer to the time when the image object was created;

- They refer to the users of the image object;

- Others.

A score was assigned to the "Flexibility" quality that arose from the sum of the number of questions corresponding to each new category. In other words, in the tests in which at least two perspectives appeared, the quality of "flexibility" was assigned the sum of the number of questions of new criteria, taking as the first criterion the one with the highest number of questions. In the event that all the questions of a student correspond to the same category, the score " 0 " was assigned for this quality.

\section{Criteria defined for assigning processing scores}

In relation to the "elaboration" the following categories were defined:

- "Concrete" (C): Questions that made reference to concrete objects visible in the images presented in the test were included in this category; 
- "Abstract" (A): Questions that referred to some abstract concept that is directly linked to the image were included in this category;

- "Double abstract" (AA): Questions that referred to concepts that do not come directly from the observation of the image were included in this category. This category was used in a single case in which it was considered that the abstraction of the questions diverged markedly from the rest of the tests. No elaborate (simple) questions were penalized by subtracting or reducing the score.

\section{Results with modified analysis of the CREA test and discussion}

The results are presented below with the modified analysis of the CREA test, for the 16 students taken as a sample:

With the changes proposed in the scores, the total values grew in all cases. Of the total of 16 students considered in this sample, 12 (75\% of them) increase their score by more than $50 \%$. Of those 12 students, 5 double or triple it. The modified scores were not compared with the scales in the CREA manual, so they were not assigned a percentile, as long as it does not apply since these scales were prepared with the original analysis. However, the modified net scores and the related information constitute a clear indication that a differentiated analysis for each of the standardized qualities of Creativity (fluidity, originality, flexibility and elaboration), can provide additional interesting and relevant information, although It takes away practicality and speed, while adding complexity to your analysis.

\section{Fluidity and originality could be overestimated.}

Given that simply writing more questions increases the likelihood of writing original options, we suggest that fluidity and originality are not independent and their measurement in a differentiated way over-estimates both qualities.

Performing the test under a stopwatch could underestimate flexibility and elaboration.

Although the time limit in 4 minutes to each lamina, can be a good strategy to measure fluidity, we understand that it can hinder the appearance of other qualities. As an example, flexibility means putting yourself in other points of view, which may require more time. In a similar way this could also be accomplished for the elaboration. As an example, writing shorter and less elaborate questions takes less time, which increases the number of questions proposed and the assessment of the CREA test analyzed according to its authors. Therefore, we consider that both flexibility and elaboration could be underestimated by the CREA test, at least applied as proposed by its authors. In this sense, the extension of time (for example, from 4 to 10 minutes for each lamina), could favor the assessment of qualities such as flexibility and elaboration, although it is clear that if applied in this way it is not appropriate to use the current scales.

It is worth mentioning that flexibility seems the most difficult quality to assess by applying the CREA test. In addition to the limited time available for the preparation of questions, another factor that may be affecting it is the way in 
which the test is requested. The CREA manual states that people should be asked to write as many questions as possible. If instead they were asked to write the largest number of different questions, this could lead to the emergence of a greater number of views and higher flexibility scores.

\section{Conclusion}

The results presented here reaffirm the difficulty of having instruments to evaluate creativity in the classroom, and demonstrate the need to continue working in this direction, as well as to critically analyze the available resources and eventually modify them. While the CREA test is easily applicable in the classroom, it may not be reliable as a global measure of creative potential.

From the results presented, it is possible to propose new hypotheses to investigate in future research:

- The CREA test could only evaluate the primary phase of creativity (of inspiration) but not the secondary creativity that involves development and elaboration.

- The modified analysis of the CREA test proposed in this work could overestimate fluidity and originality.

- The extension of the time for the application of the CREA test as well as the modification of the guideline in order to request to write the largest number of different questions, could improve the assessment of flexibility and elaboration.

\section{Acknowledgements}

This work was funded by the Education Sector Fund, in agreement between the Consejo de Formación en Educación (CFE) and the Agencia Nacional de Investigación e Innovación (ANII), Uruguay. (Project FSED_3_2017_1_142507).

\section{Conflicts of Interest}

The authors declare no conflicts of interest regarding the publication of this paper.

\section{References}

Alvarez, E. (2010). Creatividad y pensamiento divergente. Desafío de la mente o desafío del ambiente. Interac. http://www.interac.es/index.php/es/documentacion

Cachia, R., Ferrari, A., Ala-Mutka, K., \& Punie, Y. (2010). Creative Learning and Innovative Teaching. Final Report on the Study on Creativity and Innovation in Education in the EU Member States. JRC Scientific and Technical Reports. http://ftp.jrc.es/EURdoc/JRC62370.pdf

Corbalán Berná, F. J., Martínez Zaragoza, F., Donolo, D. S., Alonso Monreal, C., Tejerina Arreal, M., \& Limiñana Gras, R. M. (2003). CREA. Inteligencia Creativa. In Una medida cognitiva de la creatividad (p. 50). Madrid: TEA Ediciones.

Corbalán Berná, J. (2008). De qué se habla cuando hablamos de creatividad? Cuadernos FHyCS-UNJu, 35, 11-21. 
Csikszentmihalyi, M. (2006). Creatividad. El fluir y la psicología del descubrimiento y la invención (2nd ed.). Barcelona: Paidós.

Daud, A. M., Omar, J., Turiman, P., \& Osman, K. (2012). Creativity in Science Education. Procedia-Social and Behavioral Sciences, 59, 467-474. https://doi.org/10.1016/j.sbspro.2012.09.302

Gala, S., \& Dolores, M. (2007). La dramatización en Educación Primaria como eje del aprendizaje lúdico-creativo. Tesis Doctoral, Málaga: Universidad de Málaga. http://www.biblioteca.uma.es/bbldoc/tesisuma/16853337.pdf

Guilford, J. P. (1975). Treinta y cinco años del pensamiento divergente: Teoría de la creatividad de Guilford. Revista Estudios de Psicología, Universidad Autónoma de Madrid, (pp. 175-192). (In Romo Santos M, 1987)

Hadzigeorgiou, Y., Fokialis, P., \& Kabouropoulou, M. (2012). Thinking about Creativity in Science Education. Creative Education, 3, 603. https://doi.org/10.4236/ce.2012.35089

Huidobro Salas, T. (2004). Una definición de la creatividad a través del estudio de 24 autores seleccionados. Tesis doctoral, Universidad Complutense de Madrid, Facultad de Psicología.

Kind, P. M., \& Kind, V. (2007). Creativity in Science Education: Perspectives and Challenges for Developing School Science. Studies in Science Education, 43, 1-37. https://doi.org/10.1080/03057260708560225

MacKinnon, D. W. (1975). IPAR's Contribution to the Conceptualization and Study of Creativity. In I. Taylor, \& J. Getzels (Eds.), Perspectives in Creativity (pp. 62-80). Chicago, IL: Aldine.

Manriquez, P. L., Carrasco, V. M., Navarro, N. M., Rivera, L. M., \& Pizarro, C. T. (2005). Creatividad y Profesores. Revista Iberoamericana de Educación, 39, 1-5.

Marín, R. (1980). La creatividad. Barcelona: Ediciones CEAC.

Píriz Giménez, N. (2016). Profile of Promoters and Hindering Teachers Creativity: Own or Shared? Creative Education, 7, 1436-1443. https://doi.org/10.4236/ce.2016.710149 https://www.scirp.org/journal/PaperInformation.aspx?PaperID=68231

Píriz Giménez, N. (2017a). Cualidades creativas promovidas en la formación de docentes. InterCambios, 41, 59-63. https://doi.org/10.29156/v4.i1/6 https://dialnet.unirioja.es/servlet/articulo? codigo $=6064351$

Píriz Giménez, N. (2017b). Apropiación de TIC por estudiantes de Profesorado: Aprendiendo para enseñar. Enseñanza de las ciencias: Revista de investigación y experiencias didácticas, 2881-2886. https://www.raco.cat/index.php/Ensenanza/article/view/336971/427781

Píriz Giménez, N., Areosa, G., Cabrera, J., Cuesta, D., González, A., González, L., \& Tuboni, A. (2017). Juego sobre ritmos biológicos en un curso de Fisiología humana: Una creación de los estudiantes del Profesorado. Boletín Biológica, 38, 29-35. http://www.revistaboletinbiologica.com.ar/pdfs/N38/relatando\%20(38)\%201.pdf

Píriz Giménez, N., Mallarini, V., \& Acosta, S. (2018). Promoción del pensamiento divergente en cursos de Biofísica. Revista de Enseñanza de la Física, 30, 99-108. https://revistas.unc.edu.ar/index.php/revistaEF/article/view/22740

Rael Fuster, M. I. (2009). Capacidades creativas. Innovación y experiencias educativas, No. 14, 1-11.

Rebollo, C., \& Soubirón, E. (2014). La generación de Recursos Educativos Abiertos (REA) en el aprendizaje de la Química en la formación docente de Uruguay. In Congreso Iberoamericano de Ciencia, Tecnología, Innovación y Educación (p. 2). Buenos Aires: Congreso Iberoamericano de Ciencia, Tecnología, Innovación y Educación. 
http://www.oei.es/congreso2014/memoriactei/261.pdf

Soriano de Alencar, E. (2007). Criatividade no Contexto Educacional: Três Décadas de Pesquisa. Psicologia: Teoria e Pesquisa, 23, 45-49. https://doi.org/10.1590/S0102-37722007000500008

Sternberg, R. J., \& Lubart, T. I. (1992). Creativity: Its Nature and Assessment. School Psychology International, 13, 243 -253. https://doi.org/10.1177/0143034392133004

Tan, C. L. (2014). The Curricular and Pedagogic Creativity of Summerhill School, and Related Reflection on the Teaching in Singapore. Journal of Education and Human Development, 3, 541-557.

Trnova, E., \& Trna, J. (2014). Implementation of Creativity in Science Teacher Training. International Journal on New Trends in Education and Their Implications, 5, 54-63.

Wu, H.-Y. et al. (2014). Exploring the Critical Influential Factors of Creativity for College Students: A Multiple Criteria Decision-Making Approach. Thinking Skills and Creativity, 11, 1-21. http://www.sciencedirect.com/science/article/pii/S1871187113000606 https://doi.org/10.1016/j.tsc.2013.09.004 
Annex: Data Obtained in the Application of the CREA Test in Two Students That Illustrate the Problems Identified during Their Analysis

Student No. 1

CREA $A$

- Why are there so many media today?

- Why are we still held incommunicado?

- How does the phone work?

- Was it a genius who created it? A superior mind?

- Will it be a cash register simulating a phone?

- What was the handle for?

- How are sounds transmitted through the threads, crossing fields, cities, seas, oceans?

- Were the wires supplanted by satellites?

Conventional analysis score: 9 points, $40^{\text {th }}$ percentile

Modified analysis score: 26 points

CREA B

- Will anger be a human condition? Or rather cruelty?

- Is it mastered through pain?

- Is it not allowed to listen, hear?

- Is it possible to think for ourselves or are we always influenced by others (people, institutions, society)?

- Do we hear only what they want us to hear?

- Who decides what we should know? The dominant political system? Conventional analysis score: 8 points, $55^{\text {th }}$ percentile Modified analysis score: 40 points

Student No. 2

CREA $A$

- What year is the phone?

- Who did it?

- Why?

- Whose was it?

- Can I buy one of those?

- What is it made of?

- It's a telephone?

- Why is that so?

- What is it for?

- What color is it?

- Why is that picture there?

- Who drew it?

- Works?

- Will it be a gift?

- Is it an image or a photo? 
- What material will it be?

- Will you be in a museum?

- What country will it be from?

- It is an old device, isn't it?

- Would you like to have one like that?

- Why do not you buy it?

- Did one have your grandfather?

- Is that from the year 20 '?

- Is this the first phone that was released? Conventional analysis score: 24 points, 97 th percentile Modified analysis score: 43 points

CREA $B$

- What is this?

- Who drew it?

- What does the woman in the background wear?

- Is it a steak?

- Who are they cutting off their ears?

- Why do they do it?

- Is a dog the one below?

- Why do you cover your ears?

- What are the elders doing?

- Why did you draw this image?

- For what?

- What do these images mean?

- Where are you?

- Why does the woman have a mirror?

- Is a baby in your arms?

- Are the elderly eating?

- Are the children dressed to go to school?

- Is it a doctor who is cutting off your ear? Conventional analysis score: 17 points, $90^{\text {th }}$ percentile Modified analysis score: 32 points 